Check for updates

Seattle, Washington, USA

joanne.silberner@gmail.com

Follow Joanne on Twitter: @jsilberner

Cite this as: BMJ 2021;374:n2168

http://dx.doi.org/10.1136/bmj.n2168

Published: 17 September 2021

\title{
VACCINATION
}

\section{Covid-19: How Native Americans led the way in the US vaccination effort}

\section{Getting people to agree to covid-19 vaccination is an ongoing challenge in the US. But one demographic group shines, reports Joanne Silberner}

\section{Joanne Silberner freelance journalist}

Data from the US Centers for Disease Control and Prevention (CDC) show that Native American groups-American Indians and Alaska Natives-have consistently had the best vaccination records since covid-19 vaccination in the US began in early 2021.

The CDC's daily tracker for 13 September showed that $47.5 \%$ of American Indians and Alaska Natives were fully vaccinated. ${ }^{1}$ This compared with $41.8 \%$ of Asians, $37.8 \%$ of white Americans, and $29.9 \%$ of African Americans. The American Indian/Alaska Native group has maintained its lead since the beginning of vaccination in the first dose category as well.

Community leaders ascribe this success to two things: first, the US government's decision to allow Native American communities to control vaccine distribution; and second, traditional ethnic values including respect for elders, "community first" philosophies, and a willingness to trust science-so long as it's presented by community members themselves.

\section{Vulnerability}

Early in the pandemic there were plenty of reasons to be concerned about the toll covid-19 would take on Native American groups, who make up nearly $2 \%$ of the US population.

On many reservations multigenerational families crowd together in the same homes, and for rural American Indians especially, healthcare can be difficult to access. Health services for members of federally recognised Native American communities have long been underfunded. American Indians and Alaska Natives also have higher rates of diabetes, heart disease, asthma, and obesity, making them more vulnerable to serious covid illness. Indeed, a December 2020 report from the CDC looking at covid-19 deaths in 15 states noted a death rate nearly twice as high as in non-Hispanic white people.

One study conducted by the Kaiser Family Foundation looked at the high rates of cases, deaths, and hospital admissions among Native American populations. "They are nearly twice as likely to be infected with covid-19, three times as likely to be hospitalised, and nearly two and a half times as likely to die from the virus as white people," says Latoya Hill, one of the study authors and a senior analyst in Kaiser's Racial Equity and Health Policy Program. "So, it was going to be really important to ensure that they were able to get vaccinated."
But within the Native American community, trust in any kind of federal government action on health is low. Early European migrants deliberately spread smallpox to the vulnerable tribes, decimating the population. In the 19th century the federal government cajoled or more often forced tribes into signing treaties in which they gave away much or all of their land in exchange for land elsewhere and health services. Native American communities have been fighting for rights guaranteed in these treaties, including healthcare provision, ever since they were signed.

In Seattle, home to many urban American Indians, the covid response didn't get off on the right foot. In March 2020 the Seattle Indian Health Board (SIHB) sent a request for desperately needed personal protective equipment. When Abigail Echo-Hawk, the SIHB's chief research officer, opened the large box that came in the mail, she was horrified to find it filled not with protective equipment but with body bags.

"It was such a metaphor for how American Indians and Alaska Natives have been treated by the federal government," she tells The BMJ. "They'll send us what they need to bury us, but not what is necessary to live."

\section{Choosing the right messenger}

Echo-Hawk was named on a National Academy of Sciences committee commissioned by the US National Institutes of Health, the CDC, and the Food and Drug Administration to consider vaccine distribution. In October 2020 the committee produced recommendations calling for special consideration of Native American communities because of their higher disease and death burden.

In December 2020 the SIHB's Urban Indian Health Institute conducted a national survey of American Indians and Alaska Natives to see what challenges they would face when a vaccine was rolled out. "There was a large amount of hesitancy within our communities, but we were also able to identify cultural value systems that showed us how to ensure that messaging met what native people cared about," says Echo-Hawk. The most frequently cited reason for hesitancy was how quickly the vaccines were developed.

The survey showed that where the vaccine messaging came from was crucial. "[People] didn't want to see white government officials getting vaccinated," 
Echo-Hawk explains. "They wanted to see people within their communities.”

State and federal government messaging tends to focus on protecting oneself, but that wouldn't have worked in Native American communities. Echo-Hawk says that $74 \%$ of survey respondents said they were going to make a decision on whether to get vaccinated not on an individual level but based on the needs of their community.

Crucially, the Biden administration decided early on that it would provide a vaccine pipeline directly to Native American groups or to the Indian Health Service, which provides healthcare services directly and indirectly to American Indians and Alaska Natives. These communities didn't have to wait for states to receive their allotments or go along with state distribution strategies. "This was one time where we actually saw the government say, you know how to do it, let's see what you can do," says Echo-Hawk.

\section{Foundations of trust}

Many tribes had been preparing for the vaccine rollout for a long time. One was the Lummi Nation, a relatively small tribe with 5000 members living in the far north western corner of the continental US.

Dakotah Lane, a member and medical director of the Lummi, was concerned about the death rate from covid-19 among his peers: $5.5 \%$, compared with $1 \%$ in the surrounding county. He knew that without preparation there would be hesitancy within his community.

"Vaccines are a chicken and egg question within marginalised communities," he tells The BMJ. “They say, 'I don't want to participate in any research because I'd be a guinea pig.' And then on the flip side, when a vaccine becomes available, they say, 'I don't want the treatment because how do I know that it works in tribal communities?’”

With the permission of the Lummi tribal council and an institutional review board, Lane and others at his medical clinic prepared to ask for volunteers to receive the AstraZeneca vaccine. But in autumn 2020 - three days after the tribal council had OK'd participation in the trial-news hit about transverse myelitis (inflammation of the spinal cord) in a volunteer. Lane said that he had trouble getting direct answers from AstraZeneca, so the tribe switched its interest to the experimental Novavax vaccine that was in trials.

It was easy to give the elderly community leaders the vaccines first (as Lane says, “It wasn't a hard sell”). Because of the vaccine research questions, many had already been digesting information about the virus and the vaccines over several months, and they noticed that SARS-CoV-2 was hitting older people the worst.

When more vaccine became available the elders, who were already vaccinated, found it easy to recommend it. "In our community, people still listen to our elders,” Lane explains. When he heard about people refusing the vaccine, he talked to people they trusted. "I'd talk to their grandpa, their grandma."

With a steady supply of vaccine, the tribe was able to move quickly to vaccinate clinic members and first responders and then to others living on the reservation. "The virus is non-discriminatory, so we can be non-discriminatory," says Lane. "Where Lummis went, we offered it-we expanded the bubble.” By mid-March 2021 this included non-Lummi teachers in the local school district ("Teachers crying tears of gratitude," read one local headline), as well as bus drivers and restaurant workers.
"Every vaccine in the arm is one less person who is going to get sick, and that eventually protects the whole community," says Lane. "It's in our culture to share."

\section{Lessons for the wider US}

For the SIHB, being able to make its own decisions meant being able to define who was elderly. Whereas most states started vaccination with people aged 65 and older, the SIHB went for 50 and older. "An elder to us is a different age because of chronic health disparities," says Echo-Hawk.

And, like the Lummi, the SIHB quickly began vaccinating non-community members who worked in the community. "We needed them to help reach the most vulnerable, and we needed for them to be safe," says Echo-Hawk. As of 13 September, $89 \%$ of American Indians and Alaska Natives aged 12 and over in King County, where SIHB is located, were fully vaccinated, compared with $72 \%$ of white Americans.

Native American communities in other parts of the country were also successful, some remarkably so. By March 2021, 95\% of the Blackfeet tribe in Montana had received their first vaccines.

Latoya Hill credits several factors, including allowing community leaders to make their own decisions about prioritising and distributing vaccines and incorporating cultural values and trusted community members as advocates. Plus, she notes, the government sent plentiful supplies. These are lessons for other groups, says Hill, as they underscore the importance of community centred and community driven efforts in providing access to equitable healthcare.

The next challenge is reaching the vaccine hesitant people. In Echo-Hawk's December 2020 survey, three quarters of respondents said that they would get vaccinated. She's unsure whether this will hold: recent talk of booster shots has left some people concerned about whether the vaccines work at all. But she remains confident.

"As native people we recognise that the health of our families is the health of all the families we live and work with," she says. "This country needs to go back to public health values. They need to learn from Indians.”

Competing interests: None declared.

Commissioning and peer review: Commissioned, not externally peer reviewed.

Centers for Disease Control and Prevention. Covid data tracker: percent of people receiving covid vaccine by race/ethnicity and date reported to CDC, United States. 2021.

https://covid.cdc.gov/covid-data-tracker/\#vaccinaation-demographics-trends.

This article is made freely available for use in accordance with BMJ's website terms and conditions for the duration of the covid-19 pandemic or until otherwise determined by BMJ. You may use, download and print the article for any lawful, non-commercial purpose (including text and data mining) provided that all copyright notices and trade marks are retained. 